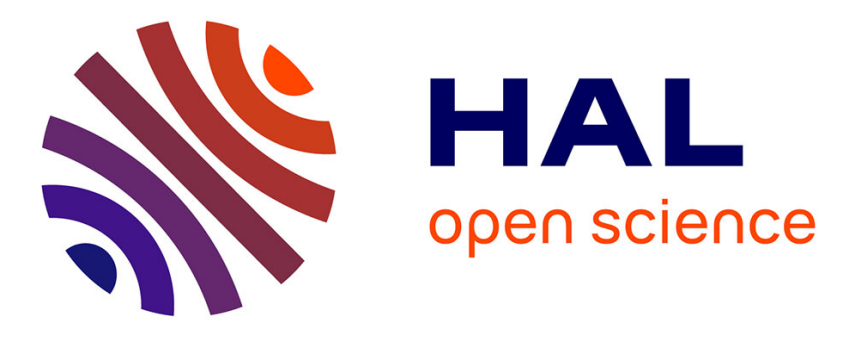

\title{
Synthesis of Profluorescent Strigolactone Probes for Biochemical Studies
}

\author{
Alexandre de Saint Germain, Guillaume Clavé, François-Didier Boyer
}

\section{To cite this version:}

Alexandre de Saint Germain, Guillaume Clavé, François-Didier Boyer. Synthesis of Profluorescent Strigolactone Probes for Biochemical Studies. "Strigolactones" edited by SpringerNature, , pp.219231, 2021, 978-1-0716-1429-7. 10.1007/978-1-0716-1429-7_17. hal-03011263

\section{HAL Id: hal-03011263 https://hal.science/hal-03011263}

Submitted on 18 Nov 2020

HAL is a multi-disciplinary open access archive for the deposit and dissemination of scientific research documents, whether they are published or not. The documents may come from teaching and research institutions in France or abroad, or from public or private research centers.
L'archive ouverte pluridisciplinaire HAL, est destinée au dépôt et à la diffusion de documents scientifiques de niveau recherche, publiés ou non, émanant des établissements d'enseignement et de recherche français ou étrangers, des laboratoires publics ou privés. 


\section{Chapter's title: Profluorescent strigolactone probes for biochemical studies}

2

Authors: Alexandre de Saint Germain ${ }^{1}$, Guillaume Clavé ${ }^{2}$ and François-Didier Boyer ${ }^{2,3}$

4

${ }^{1}$ Université Paris-Saclay, INRAE, AgroParisTech, Institut Jean-Pierre Bourgin, 78000, Versailles, France

${ }^{2}$ Université Paris-Saclay, CNRS, Institut de Chimie des Substances Naturelles, UPR 2301, 91198, Gif-surYvette, France

7

${ }^{3}$ Corresponding author: francois-didier.boyer@cnrs.fr 


\section{Running head: Profluorescent strigolactone probes}

\section{i. Summary/Abstract}

In this chapter, we will describe a method we set up to synthesize two profluorescent strigolactone (SL) mimic probes (GC240 and GC242) and the optimized protocols developed to study the enzymatic properties of various strigolactone receptors. The Arabidopsis AtD14 SL receptor is used here as a model for this purpose.

\section{ii. Key Words}

Strigolactones, Bioactive profluorescent probes, Fluorescence, $\alpha / \beta$ Hydrolase, Receptor, Enzymatic properties

\section{Introduction}

In this chapter, we present a method for characterizing strigolactone (SL) $\alpha / \beta$ hydrolase receptors containing the Ser, His and Asp catalytic triad located in the hydrophobic active site. The protocols involving direct hydrolyses of SLs have several drawbacks: large consumption of SL receptors and substrates, long reaction time for enzymatic hydrolysis and tedious HPLC analysis (1). In order to develop a more convenient assay, we designed specific profluorescent probes exhibiting high bioactivity, increased stability versus hydrolysis and better detection sensitivity. Organic fluorophores are widely used as signal reporter for many applications because they generally exhibit high sensitivity of detection (1-100 nM) depending on their brilliance (2, 3). Especially, measurement of enzyme activity in the biological sciences (4) has seen significant progress in recent years with the design of enzyme-triggerable off-on probes with high signal/background ratio (e.g., profluorophores) $(5,6)$. Contrary to classical fluorescent probes, also developed in SL research (7), they exhibit a unique selectivity due to the release of the signal following a specific event. In our case, we present here probes that inhibit shootbranching in planta (8) (see 1), but also release a fluorescent signal following their enzymatic hydrolysis. We used this smart strategy to design several bioactive profluorescent SL mimics, the most effective of which are described here (GC series, Fig. 1a). These compounds allowed us to detect the in vitro $\alpha$ - $\beta$ /hydrolase activity of RMS3 (8), the pea homolog of the SL receptor AtD14/D14/DAD2 and to highlight its velocity in the first few minutes of the reaction (9) (Fig. 1b). Noteworthy, a similar probe has also been developed by Tsuchiya et al (10). Here, we determine the kinetic constants of our probes using AtD14 protein to characterize the hydrolase activity of this SL receptor. These probes allow developing a simple bioassay for a potential high-throughput chemical screening for the discovery of putative SL receptor agonists and/or antagonists (8).

\section{Materials}




\subsection{General experimental procedures for the synthesis of profluorescent SL probes}

1. Run all non-aqueous reactions under an inert atmosphere (argon), by using standard techniques for manipulating air-sensitive compounds.

2. Store all glassware in the oven and/or it was flame-dried prior to use.

3. Obtain anhydrous solvents by filtration through drying columns or from commercial suppliers.

4. Perform analytical thin-layer chromatographies (TLC) on plates precoated with silica gel layers. Visualize compounds by one or more of the following methods: (1) illumination with a short wavelength UV lamp (i.e., $\lambda=254 \mathrm{~nm}$ ), (2) spray with a $1 \%(\mathrm{w} / \mathrm{v}) \mathrm{KMnO}_{4}$ solution in $\mathrm{H}_{2} \mathrm{O}$.

5. Perform flash column chromatography using 40-63 mesh silica.

\section{2 ( \pm )-GC240: 6,8-difluoro-4-methyl-7-[(4-methyl-5-oxo-2,5-dihydrofuran-2-yl)oxy]-2H-chromen-2-one}

1. Add to a solution of 5-bromo-3-methylfuran-2(5H)-one (26 mg, $150 \mu \mathrm{mol})$ prepared according to Wolff et al. (11) in $\mathrm{CH}_{3} \mathrm{CN}$ (1 mL) 6,8-difluoro-7-hydroxy-4-methyl-2H-chromen-2-one (DiFMU) (see 2 and 3) (16 mg, $75 \mu \mathrm{mol})$ and anhydrous $N, N$-diisopropylethylamine (DIEA) (52 $\mu \mathrm{L}, 300 \mu \mathrm{mol})$ (see 4).

2. Stir the resulting mixture at room temperature for $12 \mathrm{~h}$ and check for completion by TLC (Heptane/EtOAc 1:1).

3. Remove the solvent under vacuum.

4. Purify the resulting residue on a silica gel column (Heptane/EtOAc 6:4) giving ( \pm )-GC240 as a white solid (22 mg, $71 \mu \mathrm{mol}, 95 \%)$.

5. Obtain the following characterizations for $( \pm)-G C 240($ see 5$) . \mathrm{R}_{f}$ (heptane/EtOAc, 1:1, v/v) $=0.41$. M.p.: $191{ }^{\circ} \mathrm{C} .{ }^{1} \mathrm{H}-\mathrm{NMR}\left(300 \mathrm{MHz}, \mathrm{CDCl}_{3}\right): \delta 2.00-2.02(\mathrm{t}, J=1.4 \mathrm{~Hz}, 3 \mathrm{H}), 2.40-2.41(\mathrm{~d}, J=1.6 \mathrm{~Hz}$, $3 \mathrm{H}), 6.35(\mathrm{~s}, 1 \mathrm{H}), 6.40-6.41(\mathrm{t}, J=1.5 \mathrm{~Hz}, 1 \mathrm{H}), 7.09-7.10(\mathrm{t}, J=1.7 \mathrm{~Hz}, 1 \mathrm{H}), 7.15-7.19\left(\mathrm{dd}, J_{l}=10.3\right.$ $\left.\mathrm{Hz}, J_{2}=2.3 \mathrm{~Hz}, 1 \mathrm{H}\right)($ Fig. $2 \mathrm{a}) .{ }^{13} \mathrm{C}-\mathrm{NMR}\left(75 \mathrm{MHz}, \mathrm{CDCl}_{3}\right): \delta 10.8\left(\mathrm{CH}_{3}\right), 18.9\left(\mathrm{CH}_{3}\right), 101.1-101.2$ $(\mathrm{CH}, \mathrm{t}, J=3.0 \mathrm{~Hz}), 105.8-106.3\left(\mathrm{CH}, \mathrm{dd}, J_{l}=21.8 \mathrm{~Hz}, J_{2}=3.8 \mathrm{~Hz}\right), 116.1(\mathrm{CH}), 117.3-117.4(\mathrm{C}, \mathrm{d}, J=$ 8.7 Hz), $135.4(\mathrm{C}), 141.4(\mathrm{CH}), 142.0-142.1(\mathrm{C}, \mathrm{d}, J=5.0 \mathrm{~Hz}), 145.3-145.4(\mathrm{C}, \mathrm{d}, J=3.8 \mathrm{~Hz}), 150.0-$ $150.1(\mathrm{C}, \mathrm{d}, J=3.3 \mathrm{~Hz}), 151.1(\mathrm{C}), 153.4-153.5$ (C, d, $J=2.2 \mathrm{~Hz}$ ), 158.7 (C), 170.6 (C). IR $v_{\max }$ (film, $\left.\mathrm{cm}^{-1}\right): 701,731,753,815,832,870,883,938,955,987,1041,1102,1165,1202,1266,1300,1318$, $1340,1373,1406,1454,1508,1574,1633,1741,1776,2344,2925,3083$. HRMS (ESI): $m / z$ calc. for $\mathrm{C}_{15} \mathrm{H}_{11} \mathrm{~F}_{2} \mathrm{O}_{5}[\mathrm{M}+\mathrm{H}]^{+}:$309.0575, found: 309.0581 .

6. Prepare a $( \pm)-G C 240$ stock solution at $10 \mathrm{mM}$ in DMSO (see 6). 
1. Add sequentially DiFMU (see 2$)(21 \mathrm{mg}, 100 \mu \mathrm{mol})$ and anhydrous DIEA (70 $\mu \mathrm{L}, 400 \mu \mathrm{mol})$ (see 4) to a solution of 5-chloro-3,4-dimethylfuran-2(5H)-one (29 mg, $200 \mu \mathrm{mol})$ synthetized according to Canévet et al. (12) in $\mathrm{CH}_{3} \mathrm{CN}(1 \mathrm{~mL})$.

2. Stir the resulting mixture at room temperature for $12 \mathrm{~h}$ until the desired product precipitates.

3. Filtrate off the suspension, rinse with $\mathrm{Et}_{2} \mathrm{O}$ to give pure racemic $( \pm)$-GC242 (see 8$)$ as a white solid (31 mg, $96 \mu \mathrm{mol}, 96 \%)$.

4. Obtain the following characterizations for $\left( \pm\right.$ )-GC242 (see 5). $\mathrm{R}_{f}$ (heptane/EtOAc, 1:1, v/v) = 0.30. M.p. $181{ }^{\circ} \mathrm{C} .{ }^{1} \mathrm{H}-\mathrm{NMR}\left(300 \mathrm{MHz}, \mathrm{CDCl}_{3}\right): \delta 1.92-1.93(\mathrm{t}, J=1.2 \mathrm{~Hz}, 3 \mathrm{H}), 2.19(\mathrm{~s}, 3 \mathrm{H}), 2.42-2.43(\mathrm{~d}, J=$ $1.4 \mathrm{~Hz}, 3 \mathrm{H}), 6.17(\mathrm{~s}, 1 \mathrm{H}), 6.36(\mathrm{~s}, 1 \mathrm{H}), 7.18-7.22\left(\mathrm{dd}, J_{l}=10.3 \mathrm{~Hz}, J_{2}=2.3 \mathrm{~Hz}, 1 \mathrm{H}\right)($ Fig. $2 \mathrm{~b}) .{ }^{13} \mathrm{C}-$ NMR (75 MHz, $\left.\mathrm{CDCl}_{3}\right): \delta 8.7\left(\mathrm{CH}_{3}\right), 11.6\left(\mathrm{CH}_{3}\right), 18.9\left(\mathrm{CH}_{3}\right), 98.4(\mathrm{C}), 103.1-103.2(\mathrm{CH}, \mathrm{t}, J=3.1$ $\mathrm{Hz}), 106.0-106.3\left(\mathrm{CH}, \mathrm{dd}, J_{1}=21.8 \mathrm{~Hz}, J_{2}=3.8 \mathrm{~Hz}\right), 116.1(\mathrm{CH}), 127.7(\mathrm{C}), 141.9-142.0(\mathrm{C}, \mathrm{d}, J=5.0$ Hz), 145.3-145.4 (C, d, $J=6.5 \mathrm{~Hz}), 150.0-150.1(\mathrm{C}, \mathrm{d}, J=3.2 \mathrm{~Hz}), 151.1-151.2(\mathrm{C}, \mathrm{d}, J=2.8 \mathrm{~Hz})$, 153.2 (C), 153.4 (C), 158.7 (C), 171.2 (C). IR $v_{\max }$ (film, $\mathrm{cm}^{-1}$ ): 703, 731, 755, 841, 886, 943, 994, 1041, 1086, 1110, 1168, 1205, 1271, 1299, 1314, 1364, 1412, 1454, 1507, 1571, 1630, 1735, 1789. HRMS (ESI): $m / z$ calc. for $\mathrm{C}_{16} \mathrm{H}_{13} \mathrm{~F}_{2} \mathrm{O}_{5}[\mathrm{M}+\mathrm{H}]^{+}: 323.0731$, found: 323.0721 .

5. Prepare a $( \pm)-G C 242$ stock solution at $10 \mathrm{mM}$ in DMSO (see 6).

\subsection{Other chemicals and buffer}

1. Prepare a DiFMU stock solution at $10 \mathrm{mM}$ in DMSO (see 2).

2. Enzyme assay buffer: PBS (100 mM phosphate, $\mathrm{pH} 6.8,150 \mathrm{mM} \mathrm{NaCl})$ (see 9).

3. Milli-Q water.

4. DMSO.

\subsection{Arabidopsis strigolactone receptor protein (AtD14).}

AtD14 protein was expressed according to de Saint-Germain et al. (8) (see 10).

\subsection{Enzymatic assay}

1. Eppendorf Safe-Lock Tubes ${ }^{\mathrm{TM}}$ of $1.5-\mathrm{mL}$ capacity.

2. Falcon tubes of $15-\mathrm{mL}$ capacity.

3. Polystyrene 96 well-plates black flat bottom.

4. Pipetting robot (VIAFLO 96 Integra) (Fig. 3a). 
5. Multi-mode microplate reader (TECAN SPARK) (Fig. 3b).

6. GraphPad Prism Software.

\section{Methods}

The enzymatic activity is determined by measuring the release of fluorescent DiFMU after hydrolysis of profluorescent probes by the protein of interest (here AtD14).

\subsection{Standard profluorescent enzymatic assay}

All $100 \mu \mathrm{L}$ enzyme reactions should be carried out in 96-well plates flat bottom black polystyrene (see 10 . The expression and purification of numerous AtD14 mutant proteins and also RMS3 and mutant proteins have been done following the same method.

11). Always perform three technical replicates per condition and at least two independent experiments.

1. Start up a microplate reader and equilibrate for $30 \mathrm{~min}$ at $25^{\circ} \mathrm{C}$. Setup a program for reading 40 wells (or 96 well if you designed a full plate) and set the excitation wavelength to $365 \mathrm{~nm}$ and emission wavelength to $460 \mathrm{~nm}$ (or use appropriate filters) (see 12). Set the spectrophotometer to automatic gain. Set up a cycle to measure $90 \times$ every 20 seconds (30 min total) (see 13). During the incubation and between measurements, the reaction mixture is shaken. Prepare two distinct plates: Plate A with reaction mixture and Plate $\mathrm{B}$ with the purified enzyme (Fig. 4).

2. Prepare Plate A with the substrate:

2.1 Set up $1.2 \mathrm{~mL}$ of $80 \mu \mathrm{M}$ solution of probes to be tested (( \pm )-GC242 or $( \pm)$-GC240). Add $9.6 \mu \mathrm{L}$ of $10 \mathrm{mM}$ probes stock solution into $1.1904 \mathrm{~mL}$ of enzyme assay buffer (see Materials). The solution contains $0.8 \%$ DMSO (see 14$)$.

2.2 According to the pipetting scheme displayed in Fig. 4, pipet $50 \mu \mathrm{L}$ of probe solution into line A wells (column 1 to 4 ).

2.3 Set up $0.2 \mathrm{~mL}$ of $80 \mu \mathrm{M}$ solution of DiFMU in enzyme assay buffer for calibration curve. Add 1.6 $\mu \mathrm{L}$ of $10 \mathrm{mM}$ probes stock solution into $0.1984 \mathrm{~mL}$ of enzyme assay buffer. The solution contains $0.8 \%$ DMSO.

2.4 According to the pipetting scheme displayed in Fig. 4, pipet $100 \mu \mathrm{L}$ of DiFMU solution into line A column 5 well.

2.5 Set up $10 \mathrm{~mL}$ of $0.8 \%$ DMSO solution in enzyme assay buffer to maintain constant DMSO concentration in assay wells. 
2.6 According to the pipetting scheme displayed in Fig. 4, pipet $50 \mu \mathrm{L} 0.8 \%$ DMSO solution in enzyme assay buffer of into line B to line $\mathrm{H}$ (all columns).

2.7 Perform a serial dilution by consecutively transferring $50 \mu \mathrm{L}$ from line A to line $\mathrm{H}$ with good mixing. Trash the $50 \mu \mathrm{L}$ left over of the line H. You can use a multi-channel pipette, 12 channels.

3. Prepare Plate B with the protein

3.1 Create a $20 \mathrm{ng} / \mu \mathrm{L}(0.660 \mu \mathrm{M})$ protein solution, diluting with enzyme assay buffer (see 15$)$.

3.2 According to the plate scheme displayed in Fig. 4, add $50 \mu \mathrm{L}$ of the protein solution in the samples wells and $50 \mu \mathrm{L}$ of buffer in the control wells.

4. Add simultaneously in all wells the content $(50 \mu \mathrm{L})$ of Plate A (substrate) in Plate B (protein) using 96 tips robot) (see 16) and mix well by up and down pipetting.

5. Immediately introduce the plate B in the spectrophotometer (see 17).

6. Record fluorescence over time (at least $30 \mathrm{~min}$ ).

7. Copy the raw data from the spectrophotometer into a spreadsheet.

\subsection{Analyzing data}

1. Perform the analysis in a spreadsheet.

2. If necessary subtract the no-substrate control values from the corresponding experimental samples (see 18).

3. Generate a calibration curve using fluorescence data from the DiFMU serial dilution (column 5). The data is plotted as fluorescence at $460 \mathrm{~nm}$ versus $\mu$ moles of DiFMU.

4. Determine the slope as the fluorescence units per $\mu$ mole of DiFMU.

5. Use the slope value to calculate the quantity of DiFMU in $\mu \mathrm{M}$ produced by the protein for each time point.

6. Plot independently the data of the three samples replicates (y: $\mu \mathrm{M} \operatorname{DiFMU}, \mathrm{x}$ : time in min). A logarithmic curve should be displayed (see Fig. 5). Dependent on the kind of substrate in use, an initial increase (Initial phase $=$ pre-steady state) within the first 3 min may be observed, after which the signal plateaued (( \pm$)-G C 242)$ or slowly increased $(( \pm)-G C 240)$ (slow phase). This second phase is ascribed to the turnover reaction, when the D-ring is slowly released (Fig. 5) (see 19).

7. Identify the linear range of the initial phase, and compute the slope, $\mathrm{v}_{0}$ (= initial velocity in $\mu \mathrm{M} / \mathrm{min}$ ) for each substrate concentration.

8. Generate a table value with the initial velocities, $\mathrm{v}_{0}$, at various concentrations of profluorescent probes. 
9. Use them to obtain the kinetic parameters of the enzyme $\left(V_{\max }, K_{1 / 2}\right.$ and $\left.k_{\text {cat }}\right)$ from the MichaelisMenten curve using the GraphPad Prism software.

9.1 Create an XY table selecting "Enzyme kinetics-Michaelis- Menten" as sample data and paste the triplicates of the enzyme activities obtained for each substrate concentration.

9.2 Perform a "Nonlinear regression" analysis by selecting "Enzyme Kinetics-Substrate versus Velocity" and "Michaelis-Menten equation. Enzyme initial reaction rate, $\mathrm{v}_{0}$, at various probes concentrations were fitted to the equation $v_{0}=\frac{k_{c a t} \cdot\left[E_{t o t}\right] \cdot[S]}{K_{1 / 2}+[S]}$, where $\mathrm{v}_{0}$ is the initial reaction velocity, $k_{\text {cat }}$ the rate of the slowest step, $E_{\text {tot }}$ the total enzyme concentration, [S] the concentration of the probes, and $K_{1 / 2}$ is the probes concentration that gives half maximal velocity (see 20), in order to determine the pre-steady state enzymatic constant.

9.3 As a result of the analysis, a regression curve is superimposed on the graph (Fig. 6) and a table with the values of $V_{\max }, K_{1 / 2}$ and $k_{\text {cat }}$ together with the statistical parameters is retrieved.

\section{Notes}

1. The shoot-branching inhibition of GC240 and GC242 in pea was demonstrated using direct bud application, root feeding using hydroponic treatment and feeding to the vascular stream of shoots as described in Chapter "Methods for phenotyping shoot branching and testing SL bioactivity for shoot branching in Arabidopsis and pea" by Rameau et al.

2. DiFMU was prepared by using the multistep synthetic procedure described by Hedberg et al. (13) or is also commercially available.

3. Our first profluorescent probes were easily synthesized as a racemic mixture by nucleophilic substitution of 5bromo-4-methylfuran-2(5H)-one and 3,4-dimethylfuran-2(5H)-one with 7-hydroxycoumarine as fluorescent core. These probes were demonstrated to be as bioactive as GR24 in pea (Note 1) for the bud outgrowth inhibition. However, the similar bioactivity in pea and the better fluorescent properties of DIFMU $\left(\lambda_{\mathrm{ex}}\right.$ DIFMU > $\lambda_{\mathrm{ex}}$ 7-hydroxycoumarine and $\lambda_{\mathrm{em}} \mathrm{DiFMU}>\lambda_{\mathrm{em}}$ 7-hydroxycoumarine) prompted us to choose the DiFMU analogs (GC240, GC242) for our in vitro studies.

4. This anhydrous reagent is commercially available.

5. Nuclear magnetic resonance spectra $\left({ }^{1} \mathrm{H} ;{ }^{13} \mathrm{C}\right.$ NMR) were recorded respectively at $[300 ; 75] \mathrm{MHz}$ on a Bruker DPX 300 spectrometer. For the ${ }^{1} \mathrm{H}$ spectra, data are reported as follows: chemical shift, multiplicity $(\mathrm{s}=$ singlet, 
$\mathrm{d}=$ doublet, $\mathrm{t}=$ triplet, $\mathrm{q}=$ quartet, $\mathrm{m}=$ multiplet, $\mathrm{bs}=$ broad singulet, coupling constant in $\mathrm{Hz}$ and integration . IR spectra are reported in reciprocal centimeters $\left(\mathrm{cm}^{-1}\right)$. Mass spectra (MS) and high-resolution mass spectra (HRMS) were determined by electrospray ionization (ESI) coupled to a time-of-flight analyzer (Waters LCT Premier XE).

6. GC probes can be stored as dry solid or as mother solutions in dry DMSO (100 mM, $10 \mathrm{mM}$ or $2 \mathrm{mM})$ and kept at $-18{ }^{\circ} \mathrm{C}$. GC probes are insoluble in acetone, a common solvent used for SLs. Do not keep in water or alcohol solutions as for natural SLs, analogs and mimics.

7. As expected according to our previous results $(14,15)$ GC242 with 3,4-dimethylfuran-2(5H)-one part is as bioactive as GC240 with 4-methylfuran-2(5H)-one part and shown better stability toward nonspecific hydrolysis.

8. Resolution of the $( \pm)$-GC242 racemic mixture in the the 2 enantiomers can be done using a chiral analytical HPLC column with a 2695 HPLC Alliance from Waters coupled with a 2995 PDA Detector (Waters) and a WFCIII collector (Waters). A CHIRALPAK $®$ IA $(4.6 \times 250 \mathrm{~mm}, 5 \mu \mathrm{m})$ column was used with the eluent $55 \%$ heptane/ $45 \% \mathrm{EtOH} / \mathrm{CH}_{2} \mathrm{Cl}_{2} 9 / 1$ with $1 \mathrm{~mL} / \mathrm{min}$ as flow rate at $35^{\circ} \mathrm{C}$. Injections (each time $(15 \mu \mathrm{L})$ ) of the racemic mixture in $\mathrm{CH}_{2} \mathrm{Cl}_{2}(10 \mathrm{mg} / \mathrm{mL})$ were performed and each peak was collected. After purification, the solvent was evaporated to concentrate each enantiomer and the 2 fractions were re-injected with a concentration of $1 \mathrm{mg} / \mathrm{mL}$ to check the purity. We obtained $(+)-\mathrm{GC} 242$ (retention time $13 \mathrm{~min}) 97.5 \%\left[{ }^{\alpha} \alpha\right]_{\mathrm{D}}{ }^{20}:+100(c 0.2$ in $\left.\left.\mathrm{CHCl}_{3}\right)\right]$ for the first peak and for the second peak (-)-GC242 (retention time $\left.14.7 \mathrm{~min}\right) 99.5 \%$ of purity $\left[[\alpha]_{\mathrm{D}}{ }^{20}\right.$ : $-95\left(\right.$ c 0.5 in $\left.\left.\mathrm{CHCl}_{3}\right)\right](8)$.

9. Our protocol uses phosphate buffer $\mathrm{pH} 6.8$ because as observed with GR24, we detected a significant amount of non-enzymatic cleavage of probes at $\mathrm{pH}>7$. We also established that the enzymatic activity of AtD14 is maintained at $\mathrm{pH} 5.5$ but disappeared at $\mathrm{pH} 4.5$.

10. The expression and purification of numerous AtD14 mutant proteins and also RMS3 and mutant proteins have been done following the same method.

11. Use black microplates with flat and black bottom and avoid lid. Black microplates have low background fluorescence and minimize light scattering.

12. Before starting this protocol, ensure that you are familiar with the measurement modes of your plate reader. If your plate reader does not have monochromator, you will need to know what filters your instrument has for 
measuring DiFMU fluorescence: excitation (355 $\mathrm{nm}$ is recommended) and emission (460 $\mathrm{nm}$ is recommended) filters.

13. The recording time should be determined empirically. If the reaction is slow (not found to date with SL receptors), you should have to record during 1, 2 or 3 hours. If the reaction is too fast you should use another device to record fluorescence as stopped-flow spectrophotometer.

14. The final highest concentration of probes is divided by 2 -fold after protein addition $(40 \mu \mathrm{M})$. The probe concentrations need to be adjusted to observe an increase of enzymatic activity throughout the time and to saturate the initial velocity. The range of probe concentrations used to calculate the kinetics of the enzyme is: $0.3125,0.625,1.25,2.5,5,10,20$ and $40 \mu \mathrm{M}$.

15. The final concentration of protein is divided by 2 after substrate addition $(330 \mathrm{nM})$. The amount of recombinant enzyme added to the reaction mixture should be determined empirically. It can be increase if you don't see any signal (10-fold 100-fold even 1000-fold). If the reaction is too fast you can decrease the amount of enzyme.

16. If robot is not available to you, use a multichannel pipette at $50 \mu \mathrm{L}$ settings. Start with the blanks and then quickly proceed with the sample wells. Take care not to create any bubbles. Score the lag between the first addition and the first measurement. This lag should be added in the data curve.

17. A lag of $20 \mathrm{~s}$ is observed between the substrate addition and the first measurement. Do not forget to adjust the kinetics with this lag. If there is a lag (especially by manual pipetting) you can miss the initial phase.

18. The no-protein control fluorescence value should not increase during the half-hour assay. But if you notice a significant hydrolysis you have to subtract the values to the sample corresponding well.

19. The hydrolysis of $( \pm)$-GC240 by AtD14 is too fast to determine initial velocity.

20. $K_{1 / 2}$ is equivalent to $K_{\mathrm{m}}$, but here we quantify pre-steady state parameter therefore we cannot assimilate the dissociation constant to Michaelis constant. For this reason we call it $K_{1 / 2}$.

\section{Acknowledgement}

A.d.S.G. has received the support of the EU in the framework of the Marie-Curie FP7 COFUND People Programme, through the award of an AgreenSkills/AgreenSkills+ fellowship and G. Clavé the support of the Agence Nationale de la Recherche (contract ANR-12-BSV6-004-01). The IJPB benefits from the support of 
also acknowledged for its support. We are also grateful the Stream COST Action FA1206 for financial support.

The authors thank also Jean-Marie Beau for comments on the manuscript.

\section{References}

1. Hamiaux C, Drummond RSM, Janssen BJ, Ledger SE, Cooney JM, Newcomb RD, Snowden KC (2012) DAD2 Is an alpha/beta Hydrolase Likely to Be Involved in the Perception of the Plant Branching Hormone, Strigolactone. Curr Biol 22: 2032-2036. doi:10.1016/j.cub.2012.08.007

Sun WC, Gee KR, Haugland RP (1998) Synthesis of novel fluorinated coumarins: Excellent UV-light

excitable fluorescent dyes. Bioorg Med Chem Lett 8: 3107-3110. doi:10.1016/s0960-894x(98)00578-2

3. Shi W, Ma H (2012) Spectroscopic probes with changeable pi-conjugated systems. Chem Commun 48: 8732-8744. doi:10.1039/c2cc33366j

4. Chen X, Sun M, Ma H (2006) Progress in Spectroscopic Probes with Cleavable Active Bonds. Curr Org Chem 10: 477-489. doi:10.2174/138527206776055312

5. Bouteiller C, Clavé G, Bernardin A, Chipon B, Massonneau M, Renard P-Y, Romieu A (2007) Novel water-soluble near-infrared cyanine dyes: Synthesis, spectral properties, and use in the preparation of internally quenched fluorescent probes. Bioconjugate Chem 18: 1303-1317. doi:10.1021/bc0700281

6. Lai KS, Ho N-H, Cheng JD, Tung C-H (2007) Selective fluorescence probes for dipeptidyl peptidase activity - Fibroblast activation protein and dipeptidyl peptidase IV. Bioconjugate Chem 18: 1246-1250. doi: $10.1021 / \mathrm{bc} 0603586$

7. Van Overtveldt M, Braem L, Struk S, Kaczmarek AM, Boyer F-D, Van Deun R, Gevaert K, Goormachtig S, Heugebaert TSA, Stevens CV (2019) Design and visualization of second-generation cyanoisoindole-based fluorescent strigolactone analogs. Plant J 98: 165-180. doi:10.1111/tpj.14197

8. de Saint Germain A, Clavé G, Badet-Denisot M-A, Pillot J-P, Cornu D, Le Caer J-P, Burger M, Pelissier F, Retailleau P, Turnbull C, Bonhomme S, Chory J, Rameau C, Boyer F-D (2016) An histidine covalent receptor and butenolide complex mediates strigolactone perception. Nat Chem Biol 12: 787794. doi: $10.1038 /$ nchembio. 2147

9. Waters MT, Gutjahr C, Bennett T, Nelson DC (2017) Strigolactone Signaling and Evolution. Annu Rev Plant Biol 68: 291-322. doi:10.1146/annurev-arplant-042916-040925

10. Tsuchiya Y, Yoshimura M, Sato Y, Kuwata K, Toh S, Holbrook-Smith D, Zhang H, McCourt P, Itami K, Kinoshita T, Hagihara S (2015) Probing strigolactone receptors in Striga hermonthica with fluorescence. Science 349: 864-868. doi:10.1126/science.aab3831

11. Wolff S, Hoffmann HMR (1988) Aflatoxins revisited - convergent synthesis of the ABC-moiety. Synthesis: 760-763. doi:10.1055/s-1988-27700

12. Canévet JC, Graff Y (1978) Réactions de Friedel-Crafts de dérivés aromatiques sur des composés dicarbonylés-1,4 éthyléniques-2,3.II Alkylations par quelques hydroxy-5 ou chloro-5 dihydro-2,5 furannones-2. Nouvelle méthode de synthèse des acides $1 \mathrm{H}$-indènecarboxyliques-1. Tetrahedron 34: 1935-1942. doi:10.1016/0040-4020(78)80100-8

13. Hedberg C, Dekker FJ, Rusch M, Renner S, Wetzel S, Vartak N, Gerding-Reimers C, Bon RS, Bastiaens PI, Waldmann H (2011) Development of highly potent inhibitors of the Ras-targeting human acyl protein thioesterases based on substrate similarity design. Angew Chem Int Ed 50: 9832-9837. doi:10.1002/anie. 201102965

14. Boyer F-D, de Saint Germain A, Pillot J-P, Pouvreau J-B, Chen VX, Ramos S, Stévenin A, Simier P, Delavault P, Beau J-M, Rameau C (2012) Structure-Activity Relationship Studies of StrigolactoneRelated Molecules for Branching Inhibition in Garden Pea: Molecule Design for Shoot Branching. Plant Physiol 159: 1524-1544. doi:10.1104/pp.112.195826

15. Boyer F-D, de Saint Germain A, Pouvreau J-B, Clavé G, Pillot J-P, Roux A, Rasmussen A, Depuydt S, Lauressergues D, Frei dit Frey N, Heugebaert TSA, Stevens CV, Geelen D, Goormachtig S, Rameau C (2014) New Strigolactone Analogs as Plant Hormones with Low Activities in the Rhizosphere. Mol Plant 7: 675-690. doi:10.1093/mp/sst163

\section{List of figures}

Fig. 1 - (a) Profluorescent probes, GC series and GR24 SL synthetic analog. (b) Principle of profluorescent

probes allowing the enzymatic activity detection of AtD14 in aqueous media. 
Fig. $2-{ }^{1}$ H NMR spectrum of ( \pm )-GC240 (a) and ( \pm )-GC242 (b).

295

296

297

298

299

300

301

302

Fig. 3 - Pictures of the equipment used for the enzymatic assay. (a) An INTEGRA Viaflo 96 pipetting robot and (b) a multi-mode plate reader Spark from TECAN.

Fig. 4 - Experimental design in a 96-well plate format. Plate A. Green triangle indicates decreasing final substrate concentration from top to bottom. Green circles (columns 1 to 3) represent standard enzymatic reactions in triplicates per condition. Green circles (column 4) indicate no-protein control. Red circles (column 5) indicates DiFMU calibration curve. Plate B. Blue circles (columns 1 to 3) represent wells containing protein and corresponding standard enzymatic reactions in triplicates per condition. Grey circles (columns 4 and 5) represent wells containing buffer and corresponding to non-protein control and calibration curve.

Fig. 5 - Enzymatic kinetics for AtD14 proteins incubated with ( \pm )-GC242 or ( \pm -GC240. Progress curves during probes hydrolysis, monitored $\left(\lambda_{\mathrm{em}} 460 \mathrm{~nm}\right)$ at $25^{\circ} \mathrm{C}$. Protein catalyzed hydrolysis with $330 \mathrm{nM}$ of protein and 5 $\mu \mathrm{M}$ of probes.

Fig. 6 - Hyperbolic plot of presteady state kinetics reaction velocity with ( \pm )-GC242. Initial velocity was determined with profluorescent probes concentration from $0.3125 \mu \mathrm{M}$ to $40 \mu \mathrm{M}$ and AtD14 at $330 \mathrm{nM}$. Error bars represent SE of the mean of three replicates. 


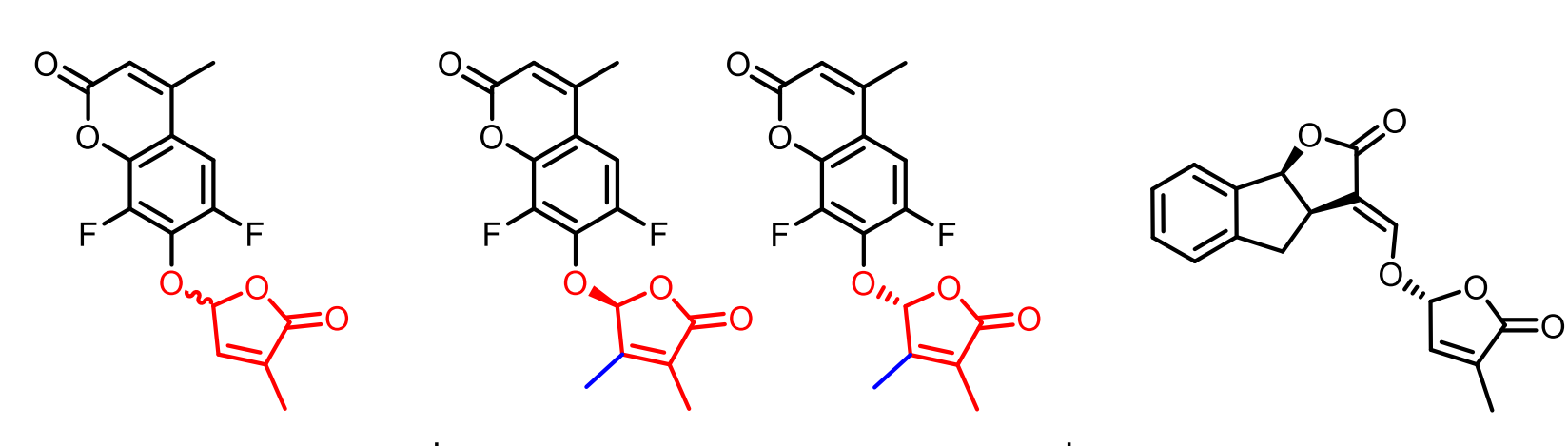

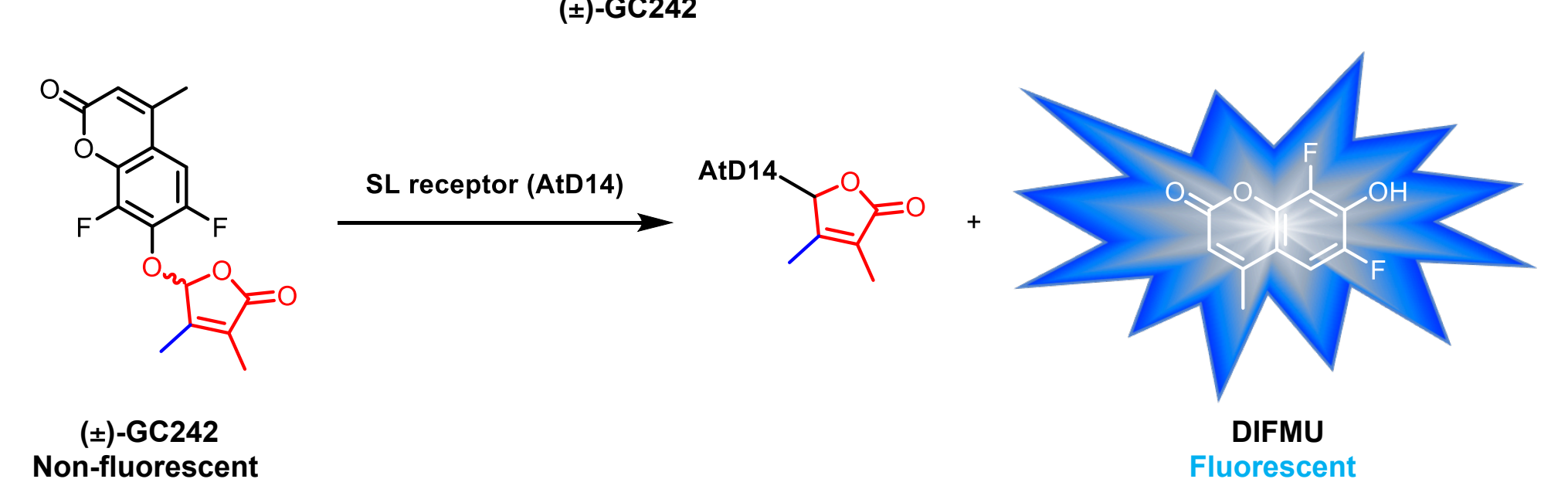




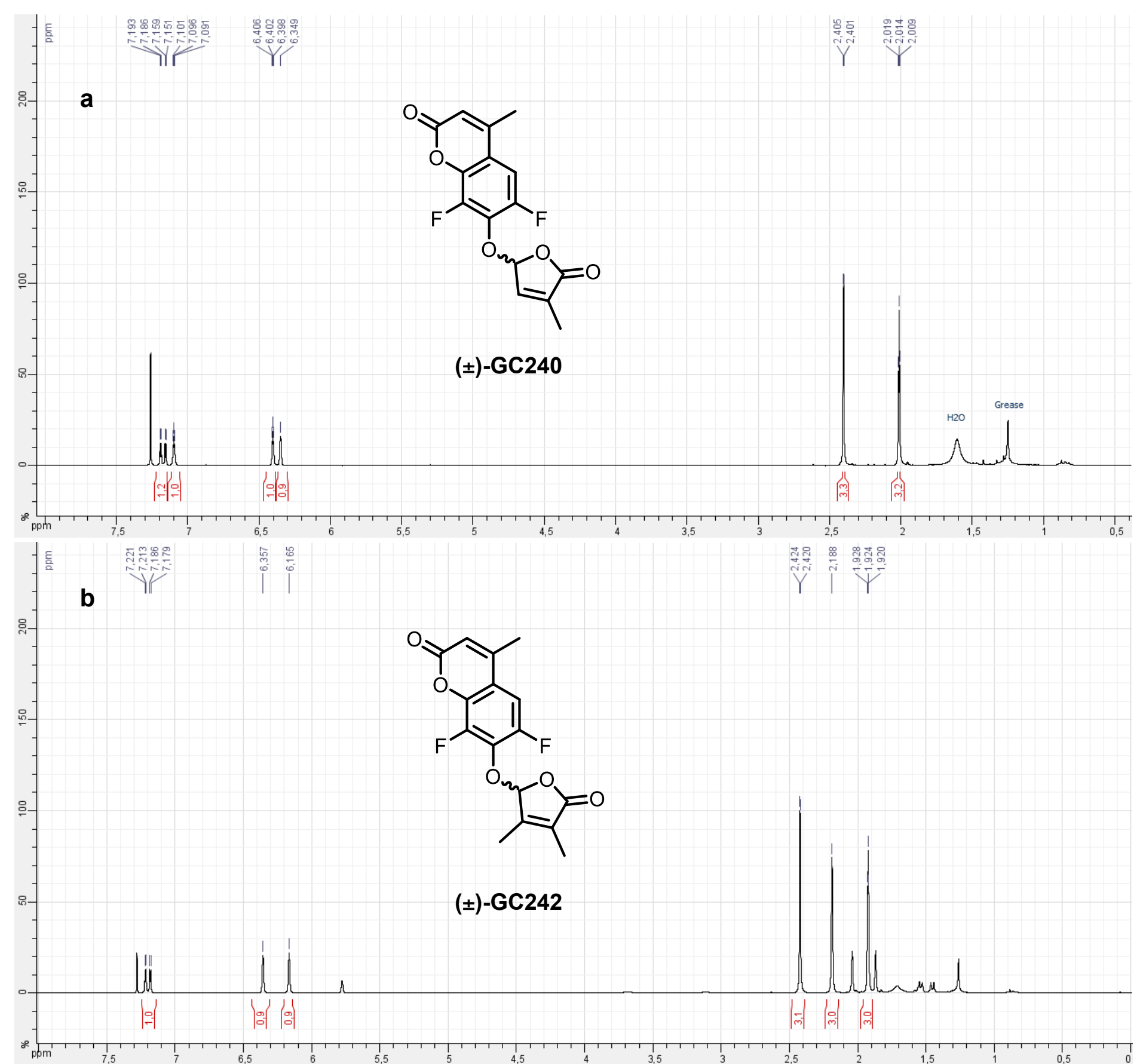



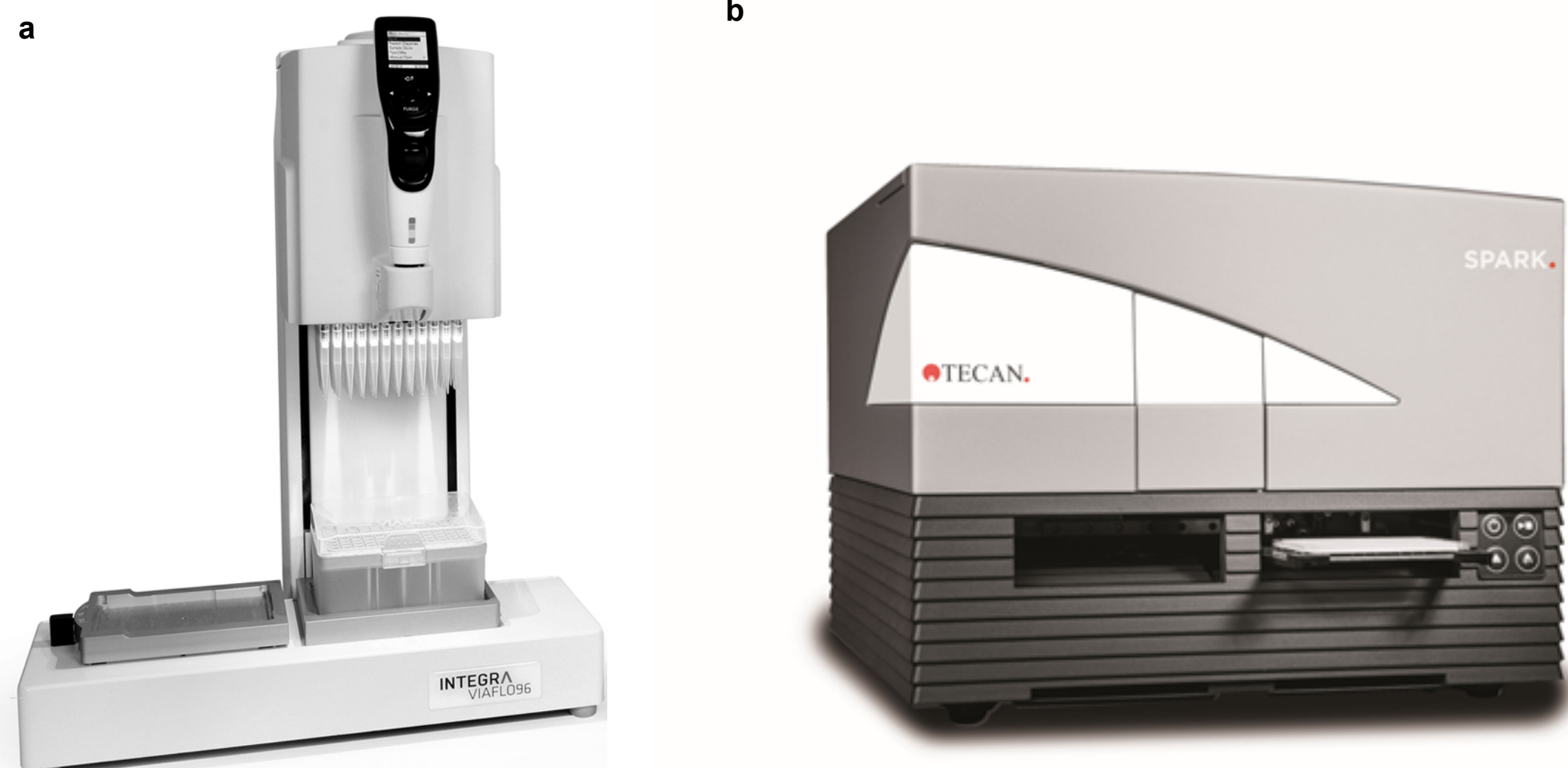

Fig. 3 

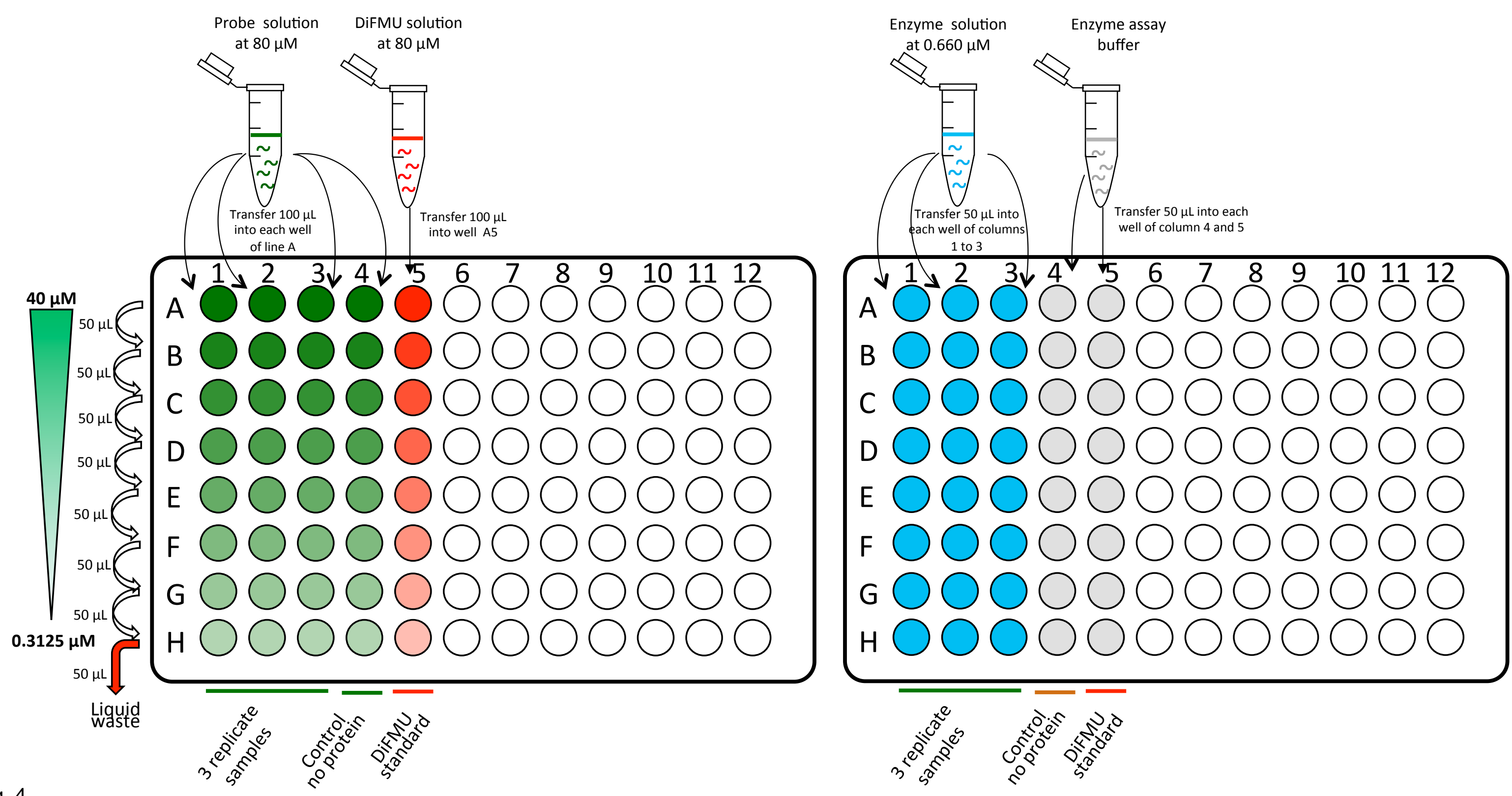


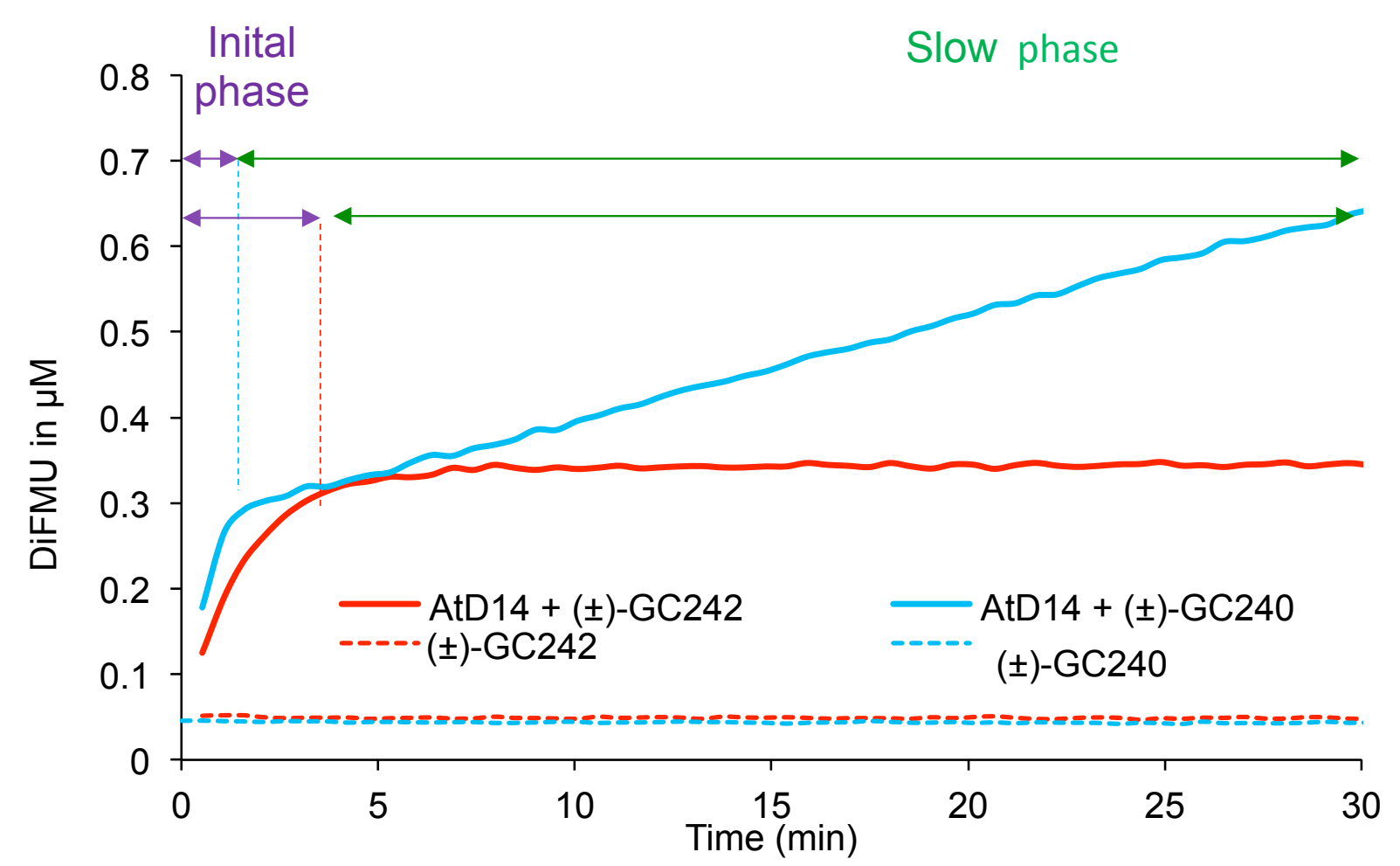

Fig. 5 


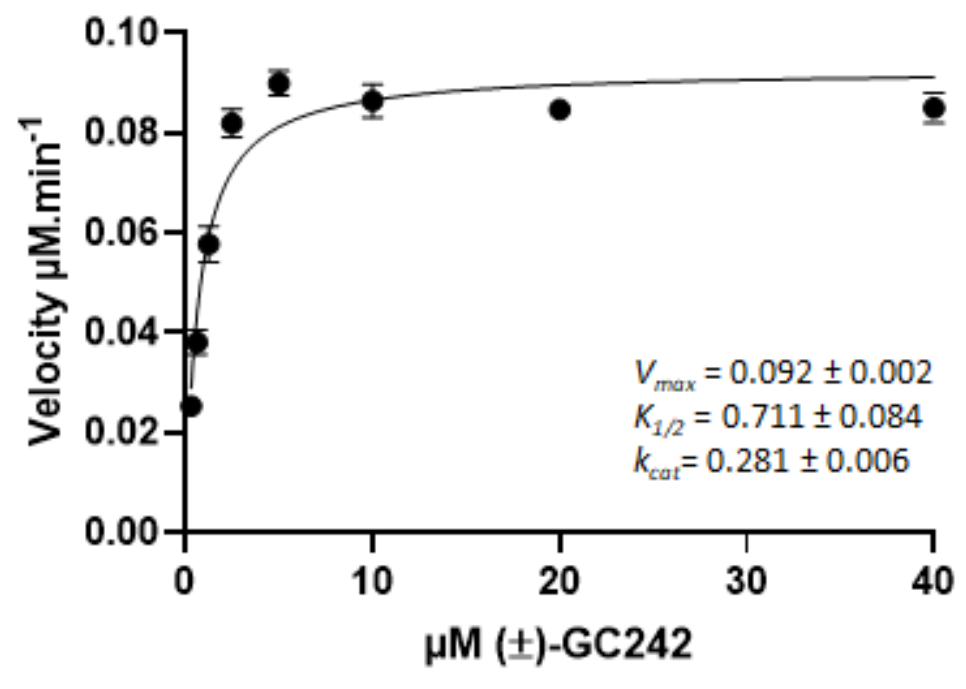

Fig. 6 